\title{
The Relationship between Entrepreneurial Self-Efficacy and Entrepreneurial Intention among University Students
}

\author{
Jennifer Wijangga, Ersa Lanang Sanjaya \\ Faculty of Psychology, Universitas Ciputra Surabaya
}

\begin{abstract}
This study aims to determine the relationship between self-efficacy in entrepreneurship with entrepreneurial intentions among university students, specifically for those who are in their final semester. As for its research method, this study uses a quantitative method to explain the relationship between variables by collecting data that has been distributed to 104 respondents. The research instrument for this study is a scale of entrepreneurial self-efficacy and an entrepreneurial intention scale, both of which meet reliability requirements. The result of the study states that there is a positive and significant relationship between self-efficacy entrepreneurship and entrepreneurial intentions.
\end{abstract}

Keywords: self-efficacy entrepreneurship, entrepreneurial intentions, university students

\section{Introduction}

Based on the data from Central Statistics Agency (Badan Pusat Statistik or BPS), there were a number of unemployed people in Indonesia in 2009 who were university graduates. This is supported by the data recorded in the International Labor Organization (ILO, 2009), that in 2009 the number of open unemployment in Indonesia amounted to 9.6 million and 10\% of them were undergraduates. Quoted from BPS data (2010), in terms of education, the number of people who had jobs with a bachelor's degree was only about 4.94 million, while the unemployment rate for those with a bachelor's degree was $14.23 \%$. This is because most university graduates focus on searching for jobs rather than creating them.

Now it is the time to give university students, especially those who are in their final semester, the knowledge on how to become entrepreneurs or creators of jobs as a prepara-

"Corresponding Author.

e-mail: jenniferwijangga96@gmail.com tion for entrepreneurship after getting a bachelor's degree. In this case, the final semester students are categorized into young adults. According to Kourilsky and Walstad (in Carsrud \& Brännback, 2009), students who are prospective college graduates need to be encouraged, and also their intentions for entrepreneurship are grown, through entrepreneurship education so that entrepreneurial passion, spirit and behavior among these young adults can grow, which has a potential to reduce unemployment, particularly among those who have obtained a bachelor's degree.

Intention is a cognitive state before someone carries out an action (Krueger, 2003). Pihie (2009) defines intention as a state of mind or attitude that can influence behavior in entrepreneurship. Entrepreneurial intentions can be defined as awareness and confidence by individuals that they have the intention to commit to entrepreneurship and plan to do so in the future (Thompson, 2009). There are many factors that can determine someone to become an entrepreneur. These factors consist of various 
Jennifer Wijangga, Ersa Lanang Sanjaya / The Relationship between Entrepreneurial Self-Efficacy and Entrepreneurial Intention among University Students / JEE, Vol. 8, No. 1, March 2019, pp. 19-24

combinations of personal attributes, traits, backgrounds, experiences, and dispositions (Arenius \& Minniti, 2005). One of these personal attributes, namely self-efficacy in entrepreneurship, is an important antecedent of the intention to open a new business (Barbosa et al., 2007).

In a study conducted by Sánchez (2011), it was also found that the main factor of entrepreneurial intention was personality measured through risk-taking and self-efficacy. So it can be concluded that entrepreneurial intention is largely influenced by personal factors (personality traits) that can be developed to obtain entrepreneurship education. According to Krueger (2003), there are several things are important factors in encouraging one's entrepreneurial intentions, one of which is self-efficacy.

Entrepreneurial self-efficacy describes selfconfidence that leads to the behavior of someone who can successfully carry out the entrepreneurial process (Hisrich et al., 2017). In the latest research, it was found that self-efficacy in entrepreneurship in individuals can be improved through training and education. Thus, individuals will have the potential to increase entrepreneurial activity (Florin et al., 2007; Mueller \& Goix, 2003; Zhao et al., 2005). Self-efficacy in entrepreneurship is considered a strong predictor in determining entrepreneurial intentions which eventually becomes a form of action (Bird, 1988; Boyd \& Vozikis, 1994).

This study aims to describe the relationship between entrepreneurial self-efficacy and entrepreneurial intentions among final year university students in a university located in Surabaya, and the question of the study is: "is there a relationship between self-efficacy in entrepreneurship towards entrepreneurial intentions among final year university students?”. We hope that the result of the study helps the society to know early on, the importance of entrepreneurship teaching, and also the strength of the potential and interest in doing entrepreneurship among the students. Moreover, the study is also aimed to find out how strong the relationship between entrepreneurial self-efficacy and entrepreneurial intentions among final year university students. In order to answer the aims described above, a hypothesis was proposed: there is a relationship between self-efficacy in entrepreneurship and entrepreneurial intention among final year university students.

\section{Method}

The study sample was 104 final year university students (semester 7-8) taken accidentally. In this study, the measurement tools (entrepreneurial self-efficacy scale) from Mueller \& Goiæ (2003), which was first developed by Stevenson et al. (1989), was modified to fit the need of this study. Self-efficacy consists of four dimensions, namely searching (planning), planning (planning), gathering (marshaling), and implementation (implementation), in which implementation is divided into people and financial. The alpha value of the search dimension is 0.819 , the planning dimension is 0.753 , the collection dimension is 0.779 . All dimensions are declared reliable because they meet the value, which is above 0.7 (Azwar, 2013). The value of self-efficacy items in each dimension is above 0.3 , with the number of items per dimension is six, thus the total items to measure selfefficacy are 30.

The entrepreneurial intention scale was modified from the Krueger's measure (Krueger, 2003) adapted by Sánchez (2011). Entrepreneurial intention variable is uni-dimensional with 
the final alpha value of 0.879 , thus this scale is declared reliable because it meets the value, which is above 0.7 (Azwar, 2013). The lowest value of entrepreneurial intention item is 0.577 and the highest is 0.827 , with the number of items is five.

\section{Results}

From the result of the frequency procedure, it is found that those who filled the questionnaire were $47.1 \%$ male and $52.9 \%$ female.

Table 1 Subject Distribution Based on Gender

\begin{tabular}{lcc}
\hline \multicolumn{1}{c}{ Gender } & N & Percentage \\
\hline Male & 49 & $47,1 \%$ \\
Female & 55 & $52,9 \%$ \\
Total & 104 & $100 \%$ \\
\hline
\end{tabular}

Based on the result of the normality test, using Kolmogorov Smirnov. The total value of the variable is not normally distributed with a significance value above 0.05 , so that the correlation calculation uses a nonparametric approach with the Spearman Rho technique. The result of Spearman Rho technique shows that there is a significant relationship with the significance value below 0.05 and the correlation coefficient of 0.595 , thus the hypothesis can be accepted, meaning that there is a relationship between entrepreneurial self-efficacy and the level of entrepreneurial intention with the direction of the relationship being a one-way direction because the correlation is positive. So if the level of entrepreneurial self-efficacy owned by individuals is high, then the level of entrepreneurial intentions possessed by these individuals is also high. In addition, the relationship between the two is quite strong.
Moreover, it was found that gender differences is a factor that distinguishes the level of self-efficacy and one's intention towards entrepreneurship. From the result obtained, the level of entrepreneurial intention in men is higher than the level of entrepreneurial intention in women.

Table 2 Cross Tabulation between Gender and Entrepreneurial Intention

\begin{tabular}{l|c|c|c|c|c|c}
\hline \multirow{2}{*}{} & \multicolumn{7}{|c}{ Entrepreneurial Intention } \\
\cline { 2 - 7 } & $\begin{array}{c}\text { Very } \\
\text { Low }\end{array}$ & Low & $\begin{array}{c}\text { Moderately } \\
\text { Low }\end{array}$ & $\begin{array}{c}\text { Moderately } \\
\text { High }\end{array}$ & High & Total \\
\hline Gender & 0 & 3 & 11 & 26 & 9 & 49 \\
1 (Male) & $0.0 \%$ & $6.1 \%$ & $22.4 \%$ & $53.1 \%$ & $18.4 \%$ & $100 \%$ \\
& 5 & 8 & 12 & 27 & 3 & 55 \\
2 (Female) & $9.1 \%$ & $14.5 \%$ & $21.8 \%$ & $49.1 \%$ & $5.5 \%$ & $100 \%$ \\
\hline
\end{tabular}

\section{Discussion}

The correlation test result shows that there is a positive and significant relationship between entrepreneurial self-efficacy with entrepreneurial intentions among final year university students. That means that this study strengthens the research conducted by Widodo \& Rusmawati (2004), that entrepreneurial selfefficacy has a correlation with entrepreneurial intention. The existence of a positive relationship between entrepreneurial self-efficacy and entrepreneurial intention shows that students with high levels of self-efficacy will have confidence in their abilities and believe that they will succeed so that they will have the intention to become entrepreneurs. It is expected that students who have the intention to become entrepreneurs will have the intention, will or high willingness to entrepreneurship so that it is expected to show a process that leads to entrepreneurial behavior.

University students need to be equipped with adequate competencies so that after graduating with a bachelor's degree, they will have 
Jennifer Wijangga, Ersa Lanang Sanjaya / The Relationship between Entrepreneurial Self-Efficacy and Entrepreneurial Intention among University Students / JEE, Vol. 8, No. 1, March 2019, pp. 19-24

the confidence in entrepreneurship (self-efficacy) so that the intention arises to be an entrepreneur. This is supported by Wall's statement (Wall, 2007) that work attitude and readiness have important roles that can influence a scholar to work later. Santrock (2008) also states that it is important to have work readiness for students to determine their careers later. Therefore, it is necessary to build entrepreneurial self-efficacy early on, which is supported by the fact that self-efficacy can be formed and improved through the education process (Hisrich et al., 2017).

The introduction of the world of entrepreneurship with comprehensive competency formation is considered important for university students (Wijaya, 2007). Entrepreneurship education for students, especially in Indonesia, is expected to be further developed and can be one of the factors driving the emergence of entrepreneurial intentions. Good education will increase students' entrepreneurial self-efficacy so that it raises entrepreneurial intention. Entrepreneurial self-efficacy is a construct that shows that behavior, cognition, and environment are interconnected. More specifically, entrepreneurial self-efficacy is defined as the level at which a person believes or believes that he can successfully start and run a new business (Bandura, 1997).

Hackett and Betz (1981) developed Bandura's theory of entrepreneurial self-efficacy, in which self-efficacy entrepreneurship is in fact an important predictor of one's entrepreneurial intentions. In simple terms, individuals with high self-efficacy on a task will tend to pursue and be persistent in doing so rather than individuals who have low self-efficacy (Bandura, 1997). This is also supported by the opinion expressed by Indarti and Rostiani (2008), that there are three factors that can influence the entrepreneurial intention among university students, one of which is entrepreneurial selfefficacy. According to Indarti and Rostiani (2008) one's self-efficacy towards the career that one will carry out illustrates the process of choosing and adjusting to one's career choices.

Entrepreneurial intention is a determination to establish, manage and develop their entrepreneurial activities. According to Indarti and Rostianti (2008) entrepreneurial intention is influenced by several factors including: demographic factors (including gender, age, educational background, parent's jobs, individual work experience), personality factors (including the need for achievement, locus of control and self-efficacy), and environmental factors (including access to capital, information and social networks).

This is in accordance with the opinion of Betz and Hackett (in Indarti and Rostiani, 2008) that one's entrepreneurial self-efficacy is a domain that describes a person's personal opinion in relation to career selection and adjustment processes. Furthermore, Esnard-Flavius (2010) reveals that one's level of entrepreneurial selfefficacy can describe the process of selection and adjustment to career choices in one's life. Therefore, it can be concluded that the higher a person's self-efficacy level towards the business world, the stronger that individual's entrepreneurial intention will be. In other words, when someone is going to open a new business, self-efficacy is needed so that the individual is able to carry out all business activities that result in success (Handaru et al., 2015).

Then, additional results obtained from cross tabulations between genders with entrepreneurial intentions shows that male subjects have a higher level of entrepreneurial intention (71.5\%) than female subjects (54.6\%). However, from 
the results obtained, the women subjects also have high level of entrepreneurial intention, even though it is not as high as entrepreneurial intention in male subjects. This is supported by several studies carried out in North America and Europe with university student samples, resulting in the finding that young men are more interested in entrepreneurial careers than young women (Zhao et al., 2005).

Several authors from different countries agree that with the rarity in involvement of women in the business world, it is necessary to consider several things, including how women face obstacles in the business world compared to men (eg, Bruni et al., 2004), different motivations between men and women in creating new businesses (eg, Bruni et al., 2004), and certain psychological characteristics that will emerge at various levels in men and women, thus creating a different attitude towards entrepreneurship (Thompson, 2009).

\section{Conclusion}

Based on the result of data analysis and discussion that has been described, it can be concluded that there is a significant relationship between entrepreneurial self-efficacy with entrepreneurial intentions among students of university $\mathrm{X}$ in Surabaya, in which both variables have a positive direction of correlation, which means the more entrepreneurial self-efficacy a person has, the higher that person's entrepreneurial intentions is. Because of that, there is a need to develop entrepreneurship skills programs for university students to improve student's entrepreneurial self-efficacy so that students' intentions for entrepreneurship emerge. It is hoped that by having entrepreneurial intentions, after graduating later or while still in college, university students will have demonstrated entrepreneurial behavior to answer the needs of this nation.

\section{References}

Arenius, P. \& Minniti, M. 2005. Perceptual Variables and Nascent Entrepreneurship. Small Business Economics, 24(3), 233-247.

Azwar, S. 2013. Metode Penelitian. Yogyakarta: Pustaka Pelajar.

Bandura, A. 1997. Self-Efficacy: The Exercise of Control. New York: W.H. Freeman \& Co.

Barbosa, S.D., Gerhardt, M.W., \& Kickul, J.R. 2007. The Role of Cognitive Style and Risk Preference on Entrepreneurial SelfEfficacy and Entrepreneurial Intentions. Journal of Leadership \& Organizational Studies, 13(4), 86-104.

Bird, B. 1988. Implementing Entrepreneurial Ideas: The Case for Intention. Academy of Management Review, 13(3), 442-453.

Boyd, N.G. \& Vozikis, G.S. 1994. The Influence of Self-Efficacy on the Development of Entrepreneurial Intentions and Actions. Entrepreneurship Theory and Practice, 18(4), 63-77.

Bruni, A., Gherardi, S., \& Poggio, B. 2004. Entrepreneur-mentality, Gender, and the Study of Women Entrepreneurs. Journal of Organizational Change Management, 17(3), 256-268.

Carsrud, A.L. \& Brännback, M. (Eds.). 2009. Understanding the Entrepreneurial Mind: Opening the Black Box. New York: Springer.

Esnard-Flavius, T. 2010. Gender, Entrepreneurial Self-Efficacy, and Entrepreneurial Atti- 
Jennifer Wijangga, Ersa Lanang Sanjaya / The Relationship between Entrepreneurial Self-Efficacy and Entrepreneurial Intention among University Students / JEE, Vol. 8, No. 1, March 2019, pp. 19-24

tude Orientations: the Case of the Caribbean. International Business \& Economics Research Journal, 9(13), 17-31.

Florin, J., Karri, R., \& Rossiter, N. 2007. Fostering Entrepreneurial Drive in Business Education: an Attitudinal Approach. Journal of Management Education, 31(1), 17-42.

Hackett, G. \& Betz, N.E. 1981. A Self-Efficacy Approach to the Career Development of Women. Journal of Vocational Behavior, 18(3), 326-339.

Handaru, A.W., Parimita, W., \& Mufdhalifah, I.W. 2015. Membangun Intensi Berwirausaha Melalui Adversity Quotient, SelfEfficacy, and Need for Achievement. Jurnal Manajemen dan Kewirausahaan, 17(2), 155-166.

Hisrich, R.D., Peters, M. P., \& Shepherd, D. A. 2017. Entrepreneurship (10th ed.). New York: McGraw-Hill Education.

ILO (International Labor Organization). 2009. World of Work Report 2009: The Global Jobs Crisis and Beyond. Geneva: ILO International Institute for Labor Studies.

Indarti, N., \& Rostiani, R. 2008. Intensi Kewirausahaan Mahasiswa: Studi Perbandingan antara Indonesia, Jepang, dan Norwegia. Jurnal Ekonomi dan Bisnis Indonesia, 23(4), 369-384.

Krueger, N. F., Jr. 2003. The Cognitive Psychology of Entrepreneurship. In Z.J. Acs \& D.B. Audretsch (Eds.), Handbook of Entrepreneurship Research: An Interdisciplinary Survey and Introduction (pp. 105140). Boston: Kluwer Academic Publishers.

Mueller, S.L. \& Goiæ, S. 2003. East-West Differences in Entrepreneurial Self-Efficacy: Implications for Entrepreneurship Educa- tion in Transition Economies. International Journal for Entrepreneurship Education, 1(4), 613-632.

Pihie, Z.A.L. 2009. Entrepreneurship as a Career Choice: An Analysis of Entrepreneurial Self-Efficacy and Intention of University Students. European Journal of Social Sciences, 9(2), 338-349.

Sánchez, J.C. 2011. University Training for Entrepreneurial Competencies: Its Impact on Intention of Venture Creation. International Entrepreneurship and Management Journal, 7(2), 239-254. Santrock, J. 2008. Educational Psychology. Boston: McGraw-Hill.

Stevenson, H.H., Roberts, M.J., \& Grousbeck, H.I. 1989. New Business Ventures and the Entrepreneur. Homewood, IL: Irwin.

Thompson, E.R. 2009. Individual Entrepreneurial Intent: Construct Clarification and Development of an Internationally Reliable Metric. Entrepreneurship Theory and Practice, 33(3), 669-694.

Wall, B. 2007. Coaching for Emotional Intelligence. New York: Amacom.

Widodo P.B. \& Rusmawati, D. 2004. Studi Korelasi Konsep Diri dan Keyakinan Diri dengan Kewirausahaan pada Mahasiswa Prodi Psikologi FK Undip Semarang. Jurnal Psikologi UNDIP, 1(1), 59-72.

Wijaya, T. 2007. Hubungan Adversity Intelligence dengan Intensi Berwirausaha. Jurnal Manajemen dan Kewirausahaan, 9(2), 117127.

Zhao, H., Seibert, S.E., \& Hills, G.E. 2005. The Mediating Role of Self-Efficacy in the Development of Entrepreneurial Intentions. Journal of Applied Psychology, 90(6), 1265-1272. 